\title{
Orchidectomy of middle-aged rats decreases liver deiodinase 1 and pituitary deiodinase 2 activity
}

\author{
Branka Šošić-Jurjević, Branko Filipović, Kostja Renko ${ }^{1}$, Vladimir Ajdžanović, \\ Milica Manojlović-Stojanoski, Verica Milošević and Josef Köhrle ${ }^{1}$ \\ Department of Cytology, Institute for Biological Research 'Siniša Stanković', University of Belgrade, Despot Stefan Boulevard 142, 11000 Belgrade, Serbia \\ ${ }^{1}$ Institut für Experimentelle Endokrinologie, Charité - Universitätsmedizin Berlin, Augustenburger Platz 1, D-13353 Berlin, Germany \\ (Correspondence should be addressed to B Šošić-Jurjević; Email: brankasj@ibiss.bg.ac.rs)
}

\begin{abstract}
Endogenous androgens are involved in regulation of thyroid function and metabolism of thyroid hormones. As serum testosterone level progressively declines with age, this regulation may change. We tested how androgen deprivation, achieved by orchidectomy, affects thyroid homeostasis in middle-aged rats. Fifteen-month-old Wistar rats were orchidectomized (Orx) or sham-operated under ketamine anesthesia $(15 \mathrm{mg} / \mathrm{kg}$ body weight). Five weeks after the surgery, animals were decapitated. Thyroids were used for histomorphometric and ultrastructural examinations and together with livers and pituitaries for real-time quantitative PCR and deiodinase (DIO) activity measurements. Serum testosterone, TSH, L-thyroxine $\left(\mathrm{T}_{4}\right)$, and cholesterol (Chol) levels were determined. As expected, middle-aged control rats had lower $(P<0 \cdot 05)$ testosterone and $\mathrm{T}_{4}$ compared with 3 -month-old males. In the Orx middle-aged group, we
\end{abstract}

detected diminished serum testosterone $(P<0 \cdot 05)$, no change in TSH and $\mathrm{T}_{4}$ levels, and higher Chol level $(P<0 \cdot 05)$, in comparison with age-matched controls. Histomorphometric analysis of thyroid tissue revealed decreased relative volume densities of follicles and colloid $(P<0 \cdot 05)$. Relevant gene expressions and DIO1 enzyme activity were not changed in the thyroids of Orx rats. Liver Dio1 gene expression and DIO1 activity were decreased $(P<0 \cdot 05)$ in comparison with the control values. Pituitary levels of TSH $\beta$, Dio1, and Dio2 mRNAs did not change, while DIO2 activity decreased $(P<0 \cdot 05)$. In conclusion, orchidectomy of middle-aged rats affected thyroid structure with no effect on serum $\mathrm{T}_{4}$ and TSH. However, decreased liver DIO1 and pituitary DIO2 enzyme activities indicate compensatoryadaptive changes in local $\mathrm{T}_{3}$ production.

Journal of Endocrinology (2012) 215, 247-256

\section{Introduction}

Homeostasis of thyroid hormone (TH) status is regulated by systemic control of TH release from the thyroid and by local enzymatic activation and inactivation of $\mathrm{TH}$ in extrathyroidal tissues that is catalyzed by iodothyronine deiodinase (DIO) enzymes. Endogenous sex steroids, both estrogen and testosterone, play an important yet poorly defined role in regulation of the hypothalamus-pituitary-thyroid (HPT) axis and TH homeostasis.

Clinical evidence demonstrated that female patients have higher incidence of thyroid dysfunction and carcinomas than men (Ron et al. 1987). However, elderly men with thyroid carcinomas have much worse prognosis than women (Morganti et al. 2005). In animal models, rats in particular, sexual dimorphism is more clearly evident than in humans: young adult males have higher serum TSH levels than females (Chen 1984, Banu et al. 2001, Marassi et al. 2007). In addition to effects on hypothalamic-pituitary hormone regulation (Donda et al. 1990, Köhrle et al. 1995, Schomburg \& Bauer
1997), both testosterone and estrogen may differently affect thyroid homeostasis in vivo by affecting thyroid follicular epithelium (Pelletier \& El-Alfy 2000, Banu et al. 2002), level of TH carrier proteins in circulation (Bisschop et al. 2006), and/or DIO enzyme activities in peripheral organs (Köhrle et al. 1995, Lisbôa et al. 2001).

Iodothyronine DIO plays an important role in maintaining systemic TH status, as well as local control of TH action. Three DIO isoenzymes have been identified in mammals (Bianco et al. 2002) so far: type 1 (DIO1), type 2 (DIO2), and type 3 (DIO3). Their expression and activity are highly development and tissue specific and depend on numerous hormonal, environmental, and nutritional factors (Köhrle 2002). DIO1 enzyme activity is mainly regulated by triiodothyronine $\left(\mathrm{T}_{3}\right.$; Köhrle 1994), but sex steroids may also be involved in this regulation. Liver DIO1 activity is higher in young male than in female rats (Harris et al. 1979, Donda et al. 1990, Miyashita et al. 1995), while pituitary DIO1 activity is lower in young males than in females (Köhrle et al. 1995, Lisbôa et al. 2001). It seems that sexual dimorphism in 
this enzyme expression and activity may change with advancing age, as was reported for DIO1 activity in mouse liver (Schomburg et al. 2007).

Hormone level changes are an important part of aging. Aside from well-documented partial decline in circulating testosterone, aging could not be clearly associated with hypothyroidism in men (Lamberts et al. 1997). However, more recent studies suggest that elderly people and centenarians have higher serum TSH concentrations than younger individuals (Surks \& Hollowell 2007, Atzmon et al. 2009). In male rats, aging is characterized by lower serum testosterone and $\mathrm{TH}$ levels, along with unchanged serum and pituitary TSH levels (Reymond et al. 1992, Ciza et al. 1995). At the level of hypothalamic-pituitary hormone regulation, aging seems to be associated with mild central hypothyroidism in both genders (Donda et al. 1990, Cizza et al. 1995).

Although numerous experimental studies have been undertaken to determine mechanisms and molecular targets of testosterone impact on thyroid homeostasis, results obtained so far are incomplete. Much more data are currently available for young than for aged animal models. The aim of our study was to determine changes in thyroid homeostasis after testosterone deprivation achieved by bilateral castration of middle-aged rats, which we used as a model of andropause. Besides hormonal, histomorphometric, and ultrastructural assessment of thyroid tissue, we examined changes in Dio gene expressions and activities, as potential molecular targets of testosterone action in the pituitary, thyroid, and liver.

\section{Materials and Methods}

\section{Experimental animals}

Male Wistar rats were housed in the unit for experimental animals at the Institute for Biological Research 'Siniša Stanković' in Belgrade, Serbia. They were kept individually under constant laboratory conditions - room temperature $\left(22 \pm 2{ }^{\circ} \mathrm{C}\right)$ and lighting (12 h light: $12 \mathrm{~h}$ darkness).

At the age of 15-16 months, animals were randomly divided into two groups: one was bilaterally orchidectomized (Orx, $n=12$ ) under ketamine anesthesia $(15 \mathrm{mg} / \mathrm{kg}$ body weight) via scrotal route. The second group ( $\mathrm{SO} ; n=12)$ was sham-operated (SO), in which testicles were exposed but not removed. Three-month-old young adult rats $(\mathrm{C} ; n=6)$ served as control group for SO middle-aged rats and were $\mathrm{SO}$ as well. Five weeks after the surgery, all animals were decapitated. Blood was collected from the trunk of both young and middle-aged animals and the sera were stored at $-70^{\circ} \mathrm{C}$.

The pituitaries, thyroids, and livers from middle-aged rats were excised and weighed. Organs from six animals were used for histological and ultrastructural examinations, while organs from another group of six animals were used for molecular and enzyme analyses.

The protocols were approved by the Animal Care and Use Committee of our Institute, following recommendations provided in the European Convention for the Protection of Vertebrate Animals used for Experimental and Other Scientific Purposes (ETS no. 123, Appendix A).

\section{Determination of serum hormone and cholesterol levels}

Total testosterone level was determined using enzyme immunoassay kit (Adaltis Italia spa, Bologna, Italy). According to the manufacturer, the lower limit of detection was $0 \cdot 2 \mathrm{ng} / \mathrm{ml}$, and the calibration range was up to $16 \mathrm{ng} / \mathrm{ml}$. The sensitivity was $0 \cdot 01 \mathrm{ng} / \mathrm{ml}$. The cross-reactivity with DHT was $10 \%$, with androstenedione $0 \cdot 8 \%$, androsterone $0 \cdot 0 \%$, and with DHEA-S $0 \cdot 0 \%$. All samples were assayed in duplicate together in one run, with intra-assay CV of $3.9 \%$.

Serum TSH was measured with a commercially available rat TSH RIA kit (Immunodiagnostics Systems GmbH, Frankfurt am Main, Germany). According to the manufacturer, the lower limit of detection was $1.03 \mathrm{ng} / \mathrm{ml}$ and the calibration range was up to $30 \mathrm{ng} / \mathrm{ml}$. The sensitivity was $0 \cdot 33 \mathrm{ng} / \mathrm{ml}$. The cross-reactivity with $\mathrm{GH}$ was $<0 \cdot 1 \%$, with $\operatorname{Prl}<0 \cdot 1 \%$, with LH $5 \cdot 1 \%$, and FSH $0 \cdot 4 \%$. All samples were assayed in duplicate together in one run, with an intra-assay CV of $6 \cdot 1 \%$.

As rat serum has a different composition of $\mathrm{TH}$ binding proteins, we adapted human total thyroxine $\left(\mathrm{T}_{4}\right)$ RIA assay (INEP, Zemun, Serbia) by dissolving the standards in rat TH-free serum (Stringer \& Wynford-Thomas 1982). The rat TH-free serum was depleted of endogenous iodothyronines by pretreatment with 8-anilino-1-naphthalenesulfonic acid followed by overnight charcoal adsorption. The calibration range of the novel RIA was from 12.5 to $500 \mathrm{nmol} / 1$, with the lower limit of detection of $6 \mathrm{nmol} / 1$. The intra-assay $\mathrm{CV}$ was $4 \cdot 7-10 \%$. The assay showed good median recoveries of about 108\% (range 94-4-115·8\%). No significant cross-reaction was observed with $\mathrm{T}_{3}$ or with reverse $\mathrm{T}_{3}\left(\mathrm{rT}_{3}\right)$.

Total serum cholesterol (Chol) was determined with colorimetric CHOD/PAP assay, according to the manufacturer's instructions (Serbolab, Kragujevac, Serbia). According to the manufacturer, the limit of detection was $0-15.6 \mathrm{mmol} / \mathrm{l}$. All samples were assayed in duplicate, with CV of $2 \%$.

\section{Histological, morphometric, and ultrastructural analyses}

Thyroid glands were excised together with trachea. One thyroid lobe $(n=6)$ was randomly chosen and further processed according to routine protocols for light microscopy. It was fixed in Bouin's fixative for $48 \mathrm{~h}$ and dehydrated in increasing concentrations of ethanol and xylene. After embedding in Histowax (Histolab Product Ab, Göteborg, Sweden), each tissue block was serially sectioned at $5 \mu \mathrm{m}$ thickness on a rotary microtome (RM 2125RT Leica Microsystems, Wetzlar, Germany). Sections were further stained with hematoxylin and eosin (HE), according to standard procedures. Morphometric analyses of thyroids were carried out on HE sections, exactly as previously reported (Sosić-Jurjević et al. 2010). In brief, four to five transversal 
sections from the anterior, central, and posterior parts of each animals thyroid were analyzed by point-counting method (Weibel 1979), using the $M_{42}$ multipurpose test grid inserted into the ocular of a Zeiss light microscope (Jena, Germany). Fifty test fields were counted per animal at a total magnification of $\times 400$.

Digital light microscopic images of thyroid tissue were made on a Leica DM RB Photo Microscope with a JVCTK $1280 \mathrm{E}$ Video Camera using the Qwin program (Leica) for the acquisition and analysis of the images.

For electron microscopy, sections of the other thyroid lobe $(n=4)$ were immersed immediately in $4 \%$ glutaraldehyde in $0 \cdot 1 \mathrm{~mol} / \mathrm{l} \mathrm{PBS}\left(\mathrm{pH} 7 \cdot 4\right.$ ) for $24 \mathrm{~h}$ and postfixed in $1 \% \mathrm{OsO}_{4}$ in the same buffer for $1 \mathrm{~h}$. Tissue samples were dehydrated in a graded alcohol series and embedded in Araldite. Ultrathin sections were cut on LKB Ultramicrotome III (type 8802A; Sweden), using diamond knife (Diatome ultra $45^{\circ}$; Diatome, Switzerland), stained with uranyl acetate and lead citrate, and examined under a MORGAGNI 268 (FEI Company, Hillsboro, OR, USA) transmission electron microscope.

\section{Sample collection and preparation of tissue homogenates}

Pituitaries, thyroids, and livers were removed, immediately frozen in liquid nitrogen, and stored at $-80^{\circ} \mathrm{C}$ for further processing. Frozen liver tissues $(n=6)$ were first pulverized under dry ice (solid $\mathrm{CO}_{2}$ ) in precooled Teflon containers, using a micro-dismembrator (B. Braun Biotech International $\mathrm{GmbH}$, Melsungen, Germany). Aliquots of the powdered tissues were stored for further processing at $-80^{\circ} \mathrm{C}$.

\section{$R N A$ extraction and quantification}

Pituitaries (for SO $n=6$; for Orx $n=4$ ) were initially homogenized with a TissueLyzer (Qiagen) and thyroids (for SO $n=6$; for Orx $n=6$ ) with Ultra Turrax (IKA Analytical, Staufen, Germany), and total RNAs were isolated using Qiagen RNeasy Mini kit (Qiagen). Total RNA from the liver tissue powder (for SO $n=6$; for Orx $n=6$ ) was isolated using the Trizol reagent (Invitrogen), according to the manufacturer's protocols. The purity and integrity of the total RNA of all samples were assessed using NanoDrop u.v.-vis spectrophotometer ND-1000 (PEQLAB, Erlangen, Germany). Absorbance ratio at 260/280 was calculated and found to be in the range of $1 \cdot 8-2 \cdot 0$ for all RNA samples.

cDNA from all tissue homogenates was generated from 500 ng total RNA, using the iScript cDNA synthesis kit (Bio-Rad Laboratories). Transcript concentrations of Dio1 (pituitary, thyroid and liver), Dio2 (pituitary), Spot14 (Thrsp) (liver), hypoxanthine guanine phosphoribosyl transferase (Hprt; pituitary, thyroid, and liver), thyroid peroxidase (Tpo; thyroid), and thyroglobulin ( $\mathrm{Tg}$; thyroid) were determined by quantitative real-time PCR (qRT-PCR) analysis. In short, primers were chosen with the help of Primer3 (http://www.bioinformatics.nl/cgi-bin/ primer3plus/primer3plus.cgi). The primer sequences were
Dio1-f: $\quad$ 5'-TTTAAGAACAACGTGGACATCAGG-3'; Dio1-r: 5'-GGTTTACCCTTGTAGCAGATCCT-3'; Dio2-f: 5'-GCGACCTGACCACC TTTTACTAG-3'; Dio2-r: $5^{\prime}$-GCAGCACATCGGTCCTCTTG-3'; TSH $\beta$-f: 5'-TACAGAGACTTCACCTACAGAACG-3'; TSH $\beta-\mathrm{r}$ : 5'-GGCAACGGGGTAGGAGAAATAAA-3'; Hprt-f: $5^{\prime}$-TTATGGACAGGACTGAAAGACTTG- $3^{\prime} ;$ Hprt-r: 5'-CAGCAGGTCAGCAAAGAACTTATA-3'; Tpo-f: $5^{\prime}$-TTGGATCTGGCATCACTGAACTT-3'; Tpo-r: $5^{\prime}$-ATCTTGTTGACCATGCTTCTGTTG-3', Tg-f: $5^{\prime}$-CCGGATATTGCAGAGACGAT-3'; Tg-r: $5^{\prime}$-GGCAAGCTTG GGATATATGGA-3'; Spot14-f: 5'-CTTACCCACCTGACCCAGAA-3'; Spot14-r: 5'-CATCGTCTTCCCTCTCGTGT- $3^{\prime}$. Amplifications were conducted in duplicate with the Absolute qPCR SYBR Green Fluorescein Mix (Thermo Fisher Scientific, Inc., ABgene products, Epsom, UK), on a RT-PCR detection system (iCycler; Bio-Rad Laboratories). The program included the following steps: initial denaturation at $95^{\circ} \mathrm{C}$ for $10 \mathrm{~min}$, followed by 40 cycles, each including a denaturation step at $95^{\circ} \mathrm{C}$ for $30 \mathrm{~s}$, an annealing step at $60^{\circ} \mathrm{C}$ for $45 \mathrm{~s}$, and an elongation step at $72{ }^{\circ} \mathrm{C}$ for $30 \mathrm{~s}$. At the end of a final elongation step at $72{ }^{\circ} \mathrm{C}$ for $3 \mathrm{~min}$ the reaction mix was cooled at $8{ }^{\circ} \mathrm{C}$.

The optimization of PCR and validation of all PCR primer sets used in this study was previously determined (http://edoc.hu-berlin.de/docviews/abstract.php?id=36909). Hprt, Gapdh, and $18 S$ rRNA were found to be most stably expressed genes in different rat tissues under different experimental conditions (methimazole or $\mathrm{T}_{4}$ treatment, gonadectomy, and subsequent hormone replacement). Based on these data, in this study, the same three genes were also used as internal controls for three replicate assays with each primer set. Similar results were obtained in terms of statistical significance for all reference genes, but $\mathrm{Hprt}$ had the most similar expression level and amplification efficiency with all examined genes in different tissues.
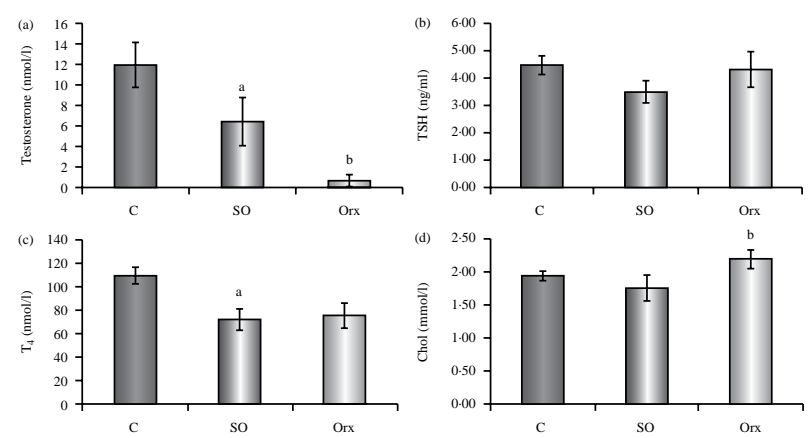

Figure 1 Serum total testosterone $(\mathrm{a}), \mathrm{TSH}(\mathrm{b})$, total thyroxine $\left(\mathrm{T}_{4} ; \mathrm{c}\right)$, and cholesterol (Chol; d) levels of control young adult (C), sham-operated (SO) and orchidectomized (Orx) middle-aged rats; serum testosterone was determined by enzyme immunoassay, while TSH and $\mathrm{T}_{4}$ were determined by RIAs. Statistics: one-way ANOVAs and Bonferroni's multiple range post hoc test. The values are mean \pm s.D.; $n=5-7$; ${ }^{\text {a }} P<0.05$ compared with $C$ rats; ${ }^{b} P<0.05$ compared with $\mathrm{SO}$ rats. 

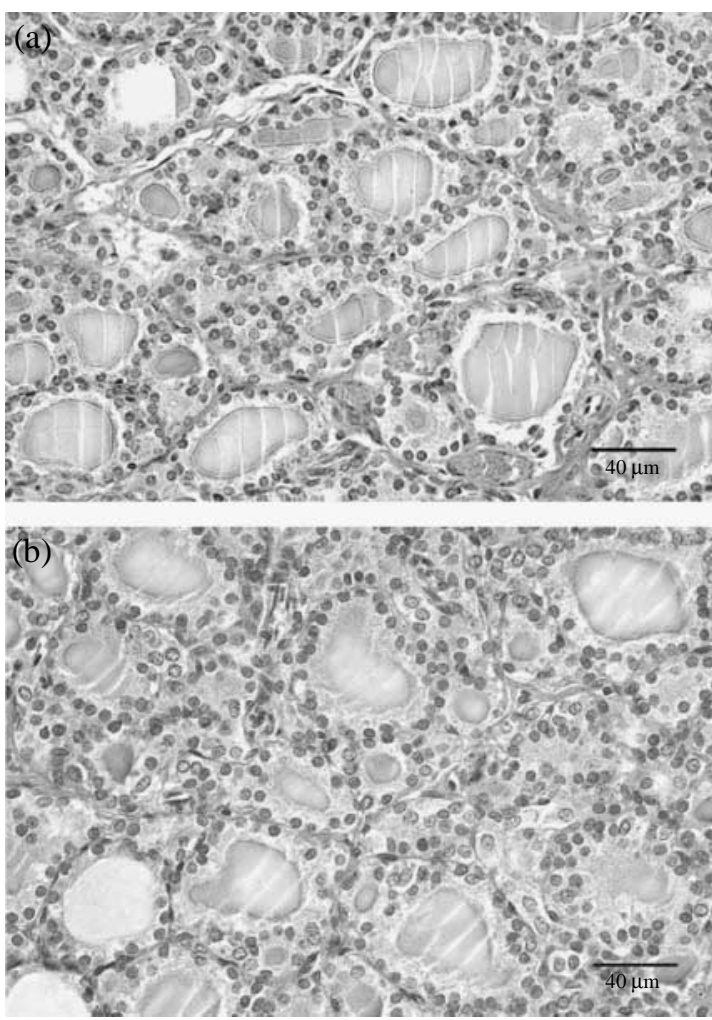

Figure 2 Thyroid gland of control sham-operated (a) and orchidectomized (b) middle-aged rat. Light microscopy, hematoxylin eosin staining.

Amplification efficiency was determined from the slopes of dilution curves and the efficiency range for all examined genes (and all examined organs) was between 84 and 107\%. Specificity of the amplification product for each primer set was verified by analytical gel electrophoresis and by melting curve analyses. None of all primer sets showed dimers in melting curves or on agarose gels. Diethylpyrocarbonate (DEPC) $\mathrm{H}_{2} \mathrm{O}$ was used as negative control instead of cDNA template.

\section{Protein extractions and $5^{\prime}$-iodothyronine DIO activity measurements}

Pituitary ( $15 \mathrm{mg} ; n=6)$ and liver tissue powder aliquots $(\sim 50 \mathrm{mg} ; n=6)$ were sonicated in 300 and $500 \mu \mathrm{l}$ of the homogenization buffer, $\mathrm{pH} 7$, respectively, on ice. The buffer contained $250 \mathrm{mmol} / \mathrm{l} \mathrm{D}(+)$-sucrose (Carl Roth, Karlsruhe, Germany), $20 \mathrm{mmol} / 1$ 4-(2-hydroxyethyl)-1-HEPES (Merck, and $0.5 \mathrm{mmol} / \mathrm{l}$ EDTA (Sigma-Aldrich), $\mathrm{pH} 8 \cdot 0$, and $1 \mathrm{mmol} / 1$ dithiothreitol (DTT; Sigma-Aldrich). After sonication $(2 \times 10$ pulses, $0.6 \mathrm{~s}$ at $200 \mathrm{~W}$; B. Braun Biotech), the membrane fraction of liver proteins was separated by centrifugation $\left(4^{\circ} \mathrm{C}, 10000 \mathrm{~g}, 10 \mathrm{~min}\right)$. The pellet was resuspended in $400 \mu \mathrm{l}$ of homogenization buffer and sonicated again.

For protein extraction from the thyroids, one thyroid lobe $(\sim 14 \mathrm{mg} ; n=6)$ was homogenized in $300 \mu \mathrm{l}$ of the same homogenization buffer on ice, using the Ultra Turrax (IKA Analytical). The homogenates were further centrifuged at $10000 \boldsymbol{g}$ for $20 \mathrm{~min}$. Supernatants were removed and pellets were resuspended in homogenization buffer. Protein concentrations were determined by a modified Bradford assay using IgG as standard (Bio-Rad).

DIO activities in pituitary, thyroid, and liver were measured based on previously described methods (Baur et al. 2000, Schomburg et al. 2006). In brief, the protein samples were assayed in a reaction mixture containing $60 \mu \mathrm{g}$ (pituitary), 7.5 $\mu \mathrm{g}$ (thyroid), or $20 \mu \mathrm{g}$ (liver) proteins. DTT $(10 \mathrm{mmol} / \mathrm{l})$ served as cofactor and $\left[{ }^{125} \mathrm{I}\right] \mathrm{rT}_{3}$ was added as tracer $(\sim 30000-80000$ c.p.m./tube, specific activity: $25 \mathrm{TBq} / \mathrm{mmol}$, PerkinElmer, Rodgau-Jügesheim, Germany). The substrate concentration was $2 \mathrm{nmol} / 1 \mathrm{rT}_{3}$ for pituitary or $1.0 \mu \mathrm{mol} / 1 \mathrm{rT}_{3}$ for both thyroid and liver. The reaction volume was $300 \mu \mathrm{l}$; the reaction proceeded at $37^{\circ} \mathrm{C}$ for $2 \mathrm{~h}$ (pituitary and thyroid) or $1 \mathrm{~h}$ (liver). Determinations of DIO1 activity were performed in sextuplicate (half in the presence and the other half in the absence of 6- $n$-propyl-2-thio-uracil, PTU). Conditions had been optimized so that deiodination of the substrate was $<15 \%$. For pituitaries and thyroids, the fraction of iodide release blocked by $1 \mathrm{mmol} / \mathrm{l}$ PTU was ascribed to DIO1. However, no thyroid DIO2 activity has been detected. Before use, $\left[{ }^{125} \mathrm{I}\right] \mathrm{rT}_{3}$ was purified from free ( ${ }^{125}$ Iodide) by chromatography using Sephadex LH-20 (Sigma-Aldrich).

After starting the enzymatic reaction by adding $\left[{ }^{125} \mathrm{I}\right] \mathrm{rT}_{3}$-containing substrate mix, the samples were incubated in a water bath at $37^{\circ} \mathrm{C}$. The reaction was stopped by adding $50 \mu \mathrm{l}$ BSA-PTU stop solutions and 10\% trichloroacetic acid for precipitation of protein. After centrifugation $\left(20^{\circ} \mathrm{C}, 14000 \mathrm{~g}, 5 \mathrm{~min}\right)$, the supernatant was transferred on Dowex-50 WX-2-column (Bio-Rad

Table 1 Morphometric parameters of the thyroid gland in sham-operated (SO) and orchidectomized (Orx) middle-aged rats. The results were obtained on four to five transversal sections from the anterior, central, and posterior parts of the thyroid, using $\mathrm{M}_{42}$ test system (50 test fields per animal) and further analyzed by an unpaired Student's $t$-test. The values are mean \pm s.D. $(n=6)$

\begin{tabular}{|c|c|c|c|c|c|c|}
\hline Group & $\boldsymbol{\tau}(\mu \mathrm{m})$ & $\mathbf{i a}=V_{\mathbf{v}} \mathbf{e} / \mathrm{V}_{\mathbf{v}} \mathbf{c}$ & $\mathbf{V}_{\mathbf{v}} \mathbf{e}(\%)$ & $\mathbf{V}_{\mathbf{v}} \mathbf{i}(\%)$ & $\mathbf{V}_{\mathbf{V}} \mathbf{c}(\%)$ & $\mathbf{V}_{\mathbf{v}} \mathbf{f}(\%)$ \\
\hline SO & $9 \cdot 9 \pm 0 \cdot 3$ & $1 \cdot 4 \pm 0 \cdot 1$ & $38 \cdot 0 \pm 2 \cdot 4$ & $32 \cdot 5 \pm 3 \cdot 9$ & $29 \cdot 5 \pm 2 \cdot 9$ & $67 \cdot 6 \pm 2$ \\
\hline Orx & $10 \cdot 4 \pm 0 \cdot 5$ & $1 \cdot 5 \pm 0.2$ & $37 \cdot 8 \pm 1 \cdot 4$ & $36 \cdot 7 \pm 1 \cdot 6 *$ & $25 \cdot 4 \pm 1.9 *$ & $63 \cdot 8 \pm 0 \cdot 7^{*}$ \\
\hline
\end{tabular}

$\tau$, the height of thyroid follicular cells; ia, index of activation rate; $\mathrm{V}_{\mathrm{v}} \mathrm{e}$, relative volume densities of epithelium; $\mathrm{V}_{\mathrm{v}} \mathrm{i}$, interstitium; $\mathrm{V}_{\mathrm{v} c}$, colloid; $\mathrm{V}_{\mathrm{v}} \mathrm{f}$, follicles. $* P<0 \cdot 05$ vs SO rats. 

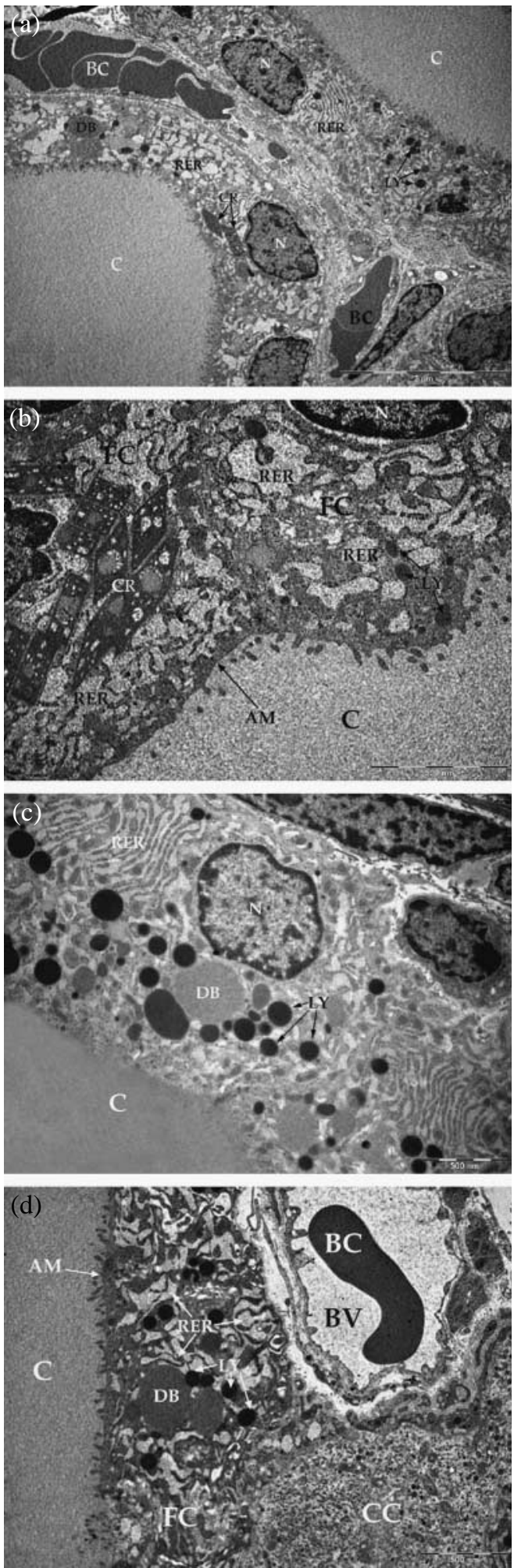

www.endocrinology-journals.org
Laboratories). Released ${ }^{125}$ Iodide was eluted by adding $10 \%$ acetic acid. 125-Iodide samples were measured on a gamma counter (Gamma Master, LKB Wallac, Turku, Finland) and background corrected. The mouse liver homogenate of known protein concentration was used as interassay variability control. After the assay, protein concentration from all samples was again determined by the Bradford assay, and the obtained results were used for calculation of the enzyme activities as described previously (Schomburg et al. 2006).

\section{Statistical analysis}

The statistical analyses were performed using GraphPad Prism v.5.01 for Windows (GraphPad Software, San Diego, CA, USA). The data are expressed as mean \pm s.D., except for qRT-PCR results, which represent mean \pm s.E.M. of the fold changes compared with basal levels of Hprt as reference gene.

One-way ANOVA was used to compare results on serum hormone and Chol levels, followed by the post hoc Bonferroni's multiple range tests to detect differences between groups. The differences in morphometric results, DIO activities and organ weights between groups were evaluated by the unpaired Student's $t$-test. The paired $t$-test was used to analyze the changes in body weight between SO and Orx groups. qRT-PCR data were calculated and evaluated using the Relative Expression Software ToolMultiple Condition Solver (REST-MCS, version 2), as described (Pfaffl 2001). The minimum level of significance was set at $P<0 \cdot 05$.

\section{Results}

\section{Body and organ weights}

The mean body weight of SO animals before the experiment was $675 \pm 72 \mathrm{~g}$ and did not significantly change by the end of the experiment $(691 \pm 59 \mathrm{~g})$. However, in the Orx group, significant body weight loss was revealed (by $11 \%, P<0 \cdot 05$ ). For the SO group, the mean pituitary, thyroid, and liver weights were $15 \pm 1.9 \mathrm{mg}, 33 \pm 3 \mathrm{mg}$, and $17.4 \pm 1.9 \mathrm{~g}$ respectively. No significant changes in organ weights were detected in the Orx group (the mean pituitary, thyroid, and liver weights were $16.3 \pm 2.9 \mathrm{mg}, 28.6 \pm 3.5 \mathrm{mg}$, and $15 \cdot 4 \pm 2 \cdot 1 \mathrm{~g}$ respectively).

\section{Serum hormone and Chol levels}

Middle-aged rats had 50 and 34\% $(P<0 \cdot 05)$ lower serum total testosterone and $\mathrm{T}_{4}$ respectively in comparison to young male adults. No age-related changes in serum TSH level were detected (Fig. 1).

Figure 3 Thyroid follicular cells (FC) from sham-operated ( $a$ and b) and orchidectomized (c and d) middle-aged rat. BC, red blood cells; $\mathrm{BV}$, blood vessel; CC, thyroid C cell; N, nucleus; RER, rough endoplasmic reticulum; LY, lysosomes; $\mathrm{DB}$, dense bodies; C, colloid; AM, apical membrane; CR, crystalline inclusions. Transmission electron microscopy. 
Surgical removal of both testicles in middle-aged rats resulted in reduced total serum testosterone by $90 \%(P<0 \cdot 05)$ compared with values obtained for age-matched $\mathrm{SO}$ controls. No change in serum concentration of TSH and total $\mathrm{T}_{4}$ was detected. Serum total Chol was 25\% higher $(P<0 \cdot 05)$ compared with the $\mathrm{SO}$ rats (Fig. 1).

\section{Thyroid gland: histomorphometric and ultrastructural findings}

Thyroid parenchyma of control SO middle-aged male rat consists of follicles of different sizes. Still, follicles composed of cuboidal follicular epithelium and moderate portion of dense luminal colloid were predominant (Fig. 2a). In Orx rat, thyroid follicles displayed a higher variation in size, and follicles of smaller size appeared more frequent in comparison with the SO rats (Fig. 2b). Further morphometric analyses demonstrated decreased relative volume of the follicles and colloid, by 15 and $17 \%(P<0 \cdot 05)$ respectively, accompanied by a $12 \%(P<0.05)$ increase in relative volume density of interstitium in Orx rats (Table 1).

Ultrastructurally, thyrocytes of middle-aged SO rats had a cuboidal shape and polar organization of organelles - oval nuclei were at the base of the cells, followed by welldeveloped rough endoplasmic reticulum (RER), lysosomes, dense bodies, and microvilli projected into the colloid at the apical surface (Fig. 3a). However, quite a few thyrocytes were characterized by dilated and disoriented RER, without losing their cuboidal shape. Some of these contained geometrically shaped (rhomboid or rectangle) crystalline inclusions, encircled by proliferated and dilated RER (Fig. 3a and b). In thyroids of Orx rats, similar ultrastructural organization of thyrocytes was observed, though no crystalline inclusions were detected (Fig. 3c and d).

Expression of genes relevant to the HPT axis in the pituitary, thyroid, and liver

In the pituitary, gene expressions of Dio1 and Dio2 and $\mathrm{TSH}$-specific $\beta$ subunit were examined. Upon quantification, no significant difference in mRNA levels of these genes was detected between $\mathrm{SO}$ and Orx groups (Fig. 4). In the thyroid, mRNA levels of Dio1, Dio2, Tg, and TPO were not significantly different between the Orx middle-aged group and $\mathrm{SO}$ rats (Fig. 5).

In the liver of Orx group, Dio1 expression was $2 \cdot 7$-fold lower $(P<0 \cdot 05)$ than the value obtained for the SO group (Fig. 6a). Expression of the Spot14 gene did not significantly differ (Fig. 6b).

\section{DIO activities in the pituitary, thyroid, and liver}

As shown in Fig. 7 orchidectomy of middle-aged male rats induced a significant decrease in pituitary DIO2 and liver DIO1 activities, by 27 and $33 \%$ respectively $(P<0 \cdot 05)$. Pituitary and thyroid DIO1 activities were unchanged in comparison to the SO controls.

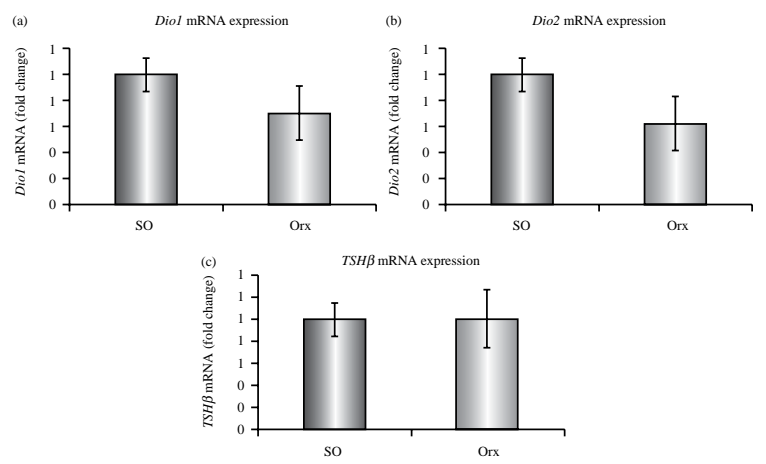

Figure 4 Gene expression of type 1 (Dio1; a) and 2 (Dio2; b) iodothyronine deiodinases and $T S H \beta$ (c) in the pituitary of shamoperated (SO; $n=6)$ and orchidectomized (Orx; $n=4)$ middle-aged rats. The relative gene expression analyses were performed by quantitative real-time PCR method. Statistics: Relative Expression Software Tool-Multiple Condition Solver, the values are mean \pm s.E.M. of the fold changes compared with basal levels of Hprt as reference gene.

\section{Discussion}

This study demonstrates that castration of middle-aged rats induces small changes in thyroid structure, namely reduction in relative volume of follicles, accompanied by the corresponding changes of some components of the HPT axis, such as reduced activities of DIO1 in the liver and DIO2 in the pituitary. Serum concentrations of TSH and TH remained unchanged.

In this experiment, orchidectomy was applied as a classical approach for studying the effects of endogenous androgens on hormonal homeostasis. As expected, orchidectomy diminished serum testosterone levels (by 90\%) in our model of andropause. A small but significant decrease in body weight was detected in the Orx group, which may be due to a skeletal muscles atrophy (Rincon et al. 1996, Axell et al. 2006) and/or decreased food intake (Gentry \& Wade 1976) induced by lack of androgens. Serum testosterone level in control middleaged males was less than half that in young adults. Other researchers also demonstrated decreases in blood testosterone concentration with advancing age (Chen et al. 1994, 1996). Age-related partial decline of serum testosterone in men is associated with decline in sexual function, muscle function, bone density, and other physiological parameters, popularly termed andropause (Harman et al. 2001, Matsumoto 2002).

In addition to the decline in serum testosterone, in our middle-aged rats, $\mathrm{T}_{4}$ levels were significantly decreased in comparison with young adult males. Thyroid tissue of SO rats was characterized by the presence of inactive follicles, distended with dense colloid. Rao-Rupanagudi et al. (1992) and other researchers (Cizza et al. 1992, Mariotti et al. 1995) also reported similar histological changes and progressive loss of follicular tissue with advancing age in the thyroid of male Sprague-Dawley or Fisher rats respectively with significant decreases in free serum TH levels. 

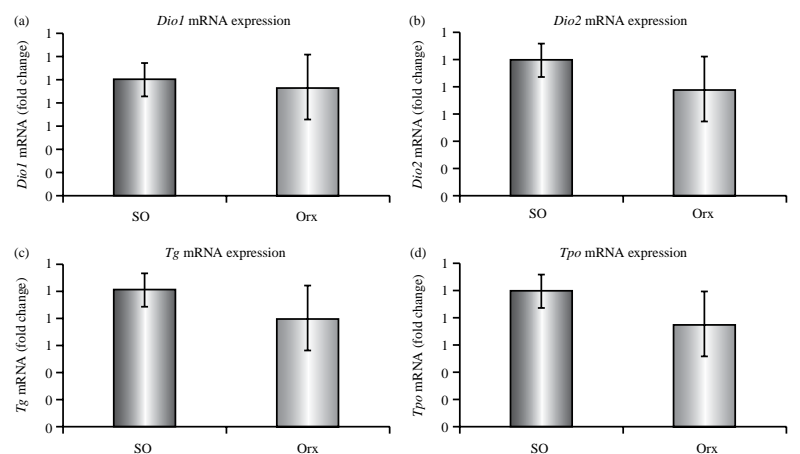

Figure 5 Gene expression of type 1 (Dio1; a) and 2 (Dio2; b) iodothyronine deiodinases, thyroglobulin $(T g ; \mathrm{c})$, and thyroid peroxidase $(T p o ; d)$ in the thyroid of sham-operated $(\mathrm{SO} ; n=6)$ and orchidectomized (Orx; $n=6$ ) middle-aged rats. The relative gene expression analyses were performed by quantitative real-time PCR method. Statistics: Relative Expression Software Tool-Multiple Condition Solver, the values are mean \pm s.E.M. of the fold changes compared with basal levels of Hprt as reference gene.

At the ultrastructural level, both in SO and in Orx middleaged rats, besides numerous follicular cells with typical organization of cell organelles, quite a few thyrocytes were characterized by dilated and distended RER cisternae. Similar ultrastructural changes were previously reported in thyrocytes of aged mouse thyroid (Tamura \& Fujita 1981, Nève \& Rondeaux 1991). Tamura \& Fujita (1981) described such ultrastructural changes in thyrocytes of 'active' follicles as degenerative. Both groups related them to follicular cell hyperactivity explained with compensation for lack of $\mathrm{TH}$ production in inactive, so-called 'cold' mice follicles. Further quantitative ultrastructural studies with rats at different life stages are needed to understand the observed features of thyrocytes under our experimental conditions.

In the thyroids of Orx middle-aged rats, no significant changes were detected in expression of genes involved in $\mathrm{TH}$ synthesis ( $T g$ and $T p o$ genes) and deiodination (Dio1 and Dio2 genes). Similar to results of our previous study (Sosić-Jurjević et al. 2010), morphometric analyses of thyroid sections revealed changes in thyroid structure, namely reduction in relative volume density of follicles and colloid. Taking all obtained results together, we suppose that these histomorphometric changes reflect increased colloid reabsorption in Orx middle-aged rats.

Apart from the hormone synthesis and secretion by the thyroid gland, deiodination pathways in liver and kidney are the main contributors to TH metabolism, turnover, and homeostasis (Schweizer et al. 2008). High levels of DIO1 activity were found in these peripheral organs, both in rats and in humans (Visser 1996). Under our experimental conditions, a decrease in liver Dio1 expression, accompanied by a corresponding decrease in enzyme activity, was detected in Orx middle-aged rats, in line with other authors who demonstrated the same for Orx prepubertal and adult rats (Miyashita et al. 1995, Lisbôa et al. 2001, Marassi et al. 2007).
As no change in serum $\mathrm{TH}$ hormones was detected in Orx middle-aged males, this effect may be attributed to testosterone deprivation. In accordance with this, Miyashita et al. (1995) demonstrated that liver DIO1 activity in young adult males was higher than in females, both in euthyroid and thyroidectomized animals.

Differential effects of sex hormones on Dio1 expression in liver and kidney were reported to change with advancing age. Thus, sexual dimorphic expression of liver Dio1 that was detected in young mice vanished at the age of 1 year, while sex-specific differences in renal Dio1 mRNA expression sustained with increasing age (Schomburg et al. 2007). Contrary to this, our results in middle-aged rats demonstrate preserved responsiveness of liver Dio1 to testosterone deprivation, while Dio1 expression in the rat kidney was not affected by castration (results not shown). Species-specific differences in age-related changes of Dio1 expression profile in the peripheral organs may indicate species-specific changes in metabolism and degradation of $\mathrm{TH}$ in aged animals. Further studies and comparisons of different animal species at different life stages are needed to determine the factors contributing to these changes.

Our results clearly demonstrate that liver DIO1 significantly decreased in Orx middle-aged rats. Decreased local production of $\mathrm{T}_{3}$ in the liver could act locally on expression of hepatic $\mathrm{T}_{3}$-responsive genes. However, we observed no change in expression of $\mathrm{T}_{3}$-regulated Spot 14 gene in Orx middle-aged rats. The responsiveness of this gene to $T_{3}$ seems to be decreased with advancing age (Mooradian et al. 1991). An increase in serum Chol level was detected in Orx middleaged males, and we cannot rule out that a local decrease in $\mathrm{T}_{3}$ level might contribute to this change. Further examinations of expression profiles of other hepatic $\mathrm{T}_{3}$-responsive genes involved in regulation of Chol metabolism are needed to evaluate the significance of Orx-induced decline in DIO1 enzyme activity to decline in hepatic $\mathrm{T}_{3}$.

We further investigated whether deprivation of endogenous androgens affects pituitary TSH synthesis and secretion and whether DIO1 and DIO2 enzymes play a role in this regulation. No significant change in TSH $\beta$ gene expression and no change in serum TSH level were detected in Orx rats in comparison to the age-matched controls. However,
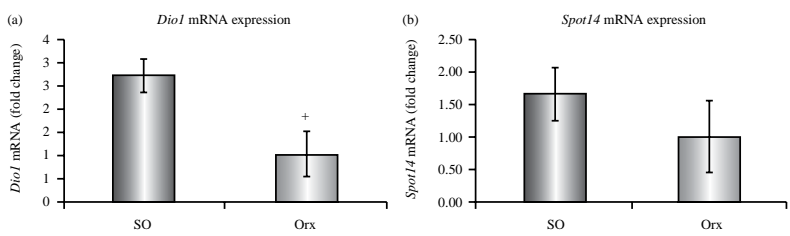

Figure 6 The expression levels of Dio1 (a) and Spot14 (b) genes in liver of sham-operated (SO; $n=6$ ) and orchidectomized (Orx; $n=6$ ) middle-aged rats; the relative gene expression analyses were performed by quantitative real-time PCR method. Statistics: Relative Expression Software Tool-Multiple Condition Solver, the values are mean \pm S.E.M. of the fold changes compared with basal levels of Hprt as reference gene; ${ }^{+} P<0 \cdot 05$ compared with $\mathrm{SO}$ rats. 

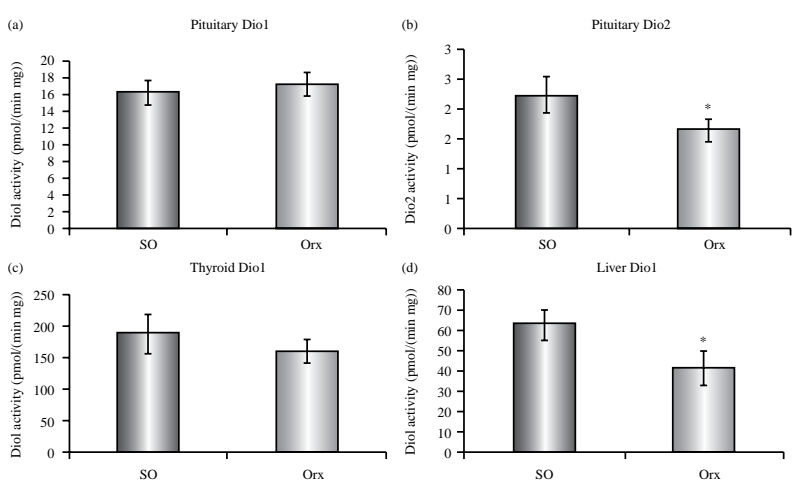

Figure 7 Enzyme activities of type 1 (DIO1) and type 2 (DIO2) iodothyronine deiodinase in pituitary ( $\mathrm{a}$ and b), thyroid (c), and liver (d) of sham-operated (SO;n=6) and orchidectomized (Orx; $n=6$ ) middle-aged rats; enzyme activities were determined using the radioactivity-based assay. The results were evaluated by unpaired Student's $t$-test. The values are mean \pm s.D.; $* P<0 \cdot 05$ compared with $\mathrm{SO}$ rats.

decreased DIO2 activity detected under our experimental conditions suggests some adaptation or compensation of local $\mathrm{T}_{3}$ production to altered thyroid or androgen status sensed by pituitary.

It was previously documented that the negative feedback control of TSH production by the anterior pituitary involves DIO enzymes, which are distinctly regulated by THs: DIO1 activity is upregulated by $\mathrm{T}_{3}$ (Köhrle 2002), while DIO2 is upregulated by low $\mathrm{T}_{4}$ (Christoffolete et al. 2006). As no change in serum $\mathrm{T}_{4}$ was detected in this experiment, decreased DIO2 activity may be attributed to lack of endogenous androgens in Orx rats.

In addition, young male rats were reported to have lower DIO1 activity in the pituitary than the females (Köhrle et al. 1995, Lisbôa et al. 2001). Besides, pituitary DIO1 activity was increased in castrated young male rats, though subsequent testosterone administration did not affect it (Lisbôa et al. 2001). Therefore, it was speculated that a difference in serum TSH between males and females is, at least, partly due to change in DIO1 enzyme activity. It is well known that castration of young adult males significantly reduces circulating levels of TSH (Christianson et al. 1981, Bagchi et al. 1984, Borges et al. 1998, Marassi et al. 2007). However, in line with the results of this study, those who examined the effects of castration in older males demonstrated no effect on TSH level in circulation (Bagchi et al. 1984, Chen 1984).

Our results, in the context of the results of other authors, implies that the role of endogenous androgens in pituitary TSH regulation diminishes with advancing age and that agerelated changes in control of DIO enzyme expression and activity may contribute to this effect. Correa da Costa \& Rosenthal (1996) reported a significantly decreased pituitary DIO2 activity in pooled pituitary samples from 10- to 12 - and 24-to 30-month-old female rats in comparison with the young adult females, while the DIO1 activity only became significant in the senescent rats. However, it is also possible that decreased local pituitary production of $\mathrm{T}_{3}$ (due to decreased DIO2) under our experimental conditions was in part compensated by $\mathrm{T}_{3}$ from the serum. Further examinations at different time points during adulthood or after prolonged Orx are needed to distinguish between these two hypotheses. In addition, androgen-modulated paracrine regulation between different pituitary cell types, which express distinct levels of DIO enzymes and/or $\mathrm{TH}$ transporters, might influence the fine tuning of anterior pituitary feedback regulation of the HPT axis with increasing age (Baur et al. 2002, Denef 2008, Liao et al. 2011).

In conclusion, our results demonstrate that orchidectomy of rats at middle age induced changes in thyroid structure with no effect on serum $\mathrm{T}_{4}$ and TSH. However, decreased activities of DIO1 in the liver and DIO2 in the pituitary indicate tissue compensation or adaptation through changes in local production of $\mathrm{T}_{3}$.

\section{Declaration of interest}

The authors declare that there is no conflict of interest that could be perceived as prejudicing the impartiality of the research reported.

\section{Funding}

This research was supported by Ministry of Education and Science of the Republic of Serbia (Grant No. 173009), and the Deutsche Forschungsgemeinschaft (DFG-GK 1208, TP3), Charité Universitätsmedizin Berlin. B Š-J was supported by DAAD fellowship (A/10/05060).

\section{Acknowledgements}

B Š-J is thankful to Prof. Dr Milka Sekulić for her guidance and to Ms Jasmina Pantelic for her assistance with the preparation of the transmission electron micrographs.

\section{References}

Atzmon G, Barzilai N, Hollowell JG, Surks MI \& Gabriely I 2009 Extreme longevity is associated with increased serum thyrotropin. Journal of Clinical Endocrinology and Metabolism 94 1251-1254. (doi:10.1210/jc. 2008-2325)

Axell AM, MacLean HE, Plant DR, Harcourt LJ, Davis JA, Jimenez M, Handelsman DJ, Lynch GS \& Zajac JD 2006 Continuous testosterone administration prevents skeletal muscle atrophy and enhances resistance to fatigue in orchidectomized male mice. American Journal of Physiology. Endocrinology and Metabolism 291 E506-E516. (doi:10.1152/ajpendo. 00058.2006)

Bagchi N, Shivers B \& Brown TR 1984 Effects of castration and sex steroids on the thyroid response to thyrotropin. Endocrinology 114 1652-1656. (doi:10.1210/endo-114-5-1652)

Banu KS, Govindarajulu P \& Aruldhas MM 2001 Testosterone and estradiol modulate TSH-binding in the thyrocytes of Wistar rats: influence of age and sex. Journal of Steroid Biochemistry and Molecular Biology 78 329-342. (doi:10.1016/S0960-0760(01)00107-8) 
Banu SK, Govindarajulu P \& Aruldhas MM 2002 Testosterone and estradiol up-regulate androgen and estrogen receptors in immature and adult rat thyroid glands in vivo. Steroids 67 1007-1014. (doi:10.1016/ S0039-128X(02)00063-6)

Baur A, Bauer K, Jarry H \& Köhrle J 2000 Effects of proinflammatory cytokines on anterior pituitary $5^{\prime}$-deiodinase type I and type II. Journal of Endocrinology 167 505-515. (doi:10.1677/joe.0.1670505)

Baur A, Buchfelder M \& Köhrle J 2002 Expression of 5'-deiodinase enzymes in normal pituitaries and in various human pituitary adenomas. European Journal of Endocrinology 147 263-268. (doi:10.1530/eje.0.1470263)

Bianco AC, Salvatore D, Gereben B, Berry MJ \& Larsen PR 2002 Biochemistry, cellular and molecular biology, and physiological roles of the iodothyronine selenodeiodinases. Endocrine Reviews 23 38-89. (doi:10.1210/er.23.1.38)

Bisschop PH, Toorians AW, Endert E, Wiersinga WM, Gooren LJ \& Fliers E 2006 The effects of sex-steroid administration on the pituitary-thyroid axis in transsexuals. European Journal of Endocrinology 155 11-16. (doi:10.1530/ eje.1.02192)

Borges PP, Curty FH, Pazos-Moura CC \& Moura EG 1998 Effect of testosterone propionate treatment on thyrotropin secretion of young and old rats in vitro. Life Sciences 62 2035-2043. (doi:10.1016/S00243205(98)00175-1)

Chen HJ 1984 Age and sex difference in serum and pituitary thyrotropin concentrations in the rat: influence by pituitary adenoma. Experimental Gerontology 19 1-6. (doi:10.1016/0531-5565(84)90025-1)

Chen H, Hardy MP, Huhtaniemi I \& Zirkin BR 1994 Age-related decreased Leydig cell testosterone production in the brown Norway rat. Journal of Andrology 15 551-557.

Chen H, Huhtaniemi I \& Zirkin BR 1996 Depletion and repopulation of Leydig cells in the testes of aging brown Norway rats. Endocrinology 137 3447-3452. (doi:10.1210/en.137.8.3447)

Christianson D, Roti E, Vagenakis AG \& Braverman LE 1981 The sex-related difference in serum thyrotropin concentration is androgen mediated. Endocrinology 108 529-535. (doi:10.1210/endo-108-2-529)

Christoffolete MA, Ribeiro R, Singru P, Fekete C, da Silva WS, Gordon DF, Huang SA, Crescenzi A, Harney JW, Ridgway EC et al. 2006 Atypical expression of type 2 iodothyronine deiodinase in thyrotrophs explains the thyroxine-mediated pituitary thyrotropin feedback mechanism. Endocrinology 147 1735-1743. (doi:10.1210/en.2005-1300)

Cizza G, Gold PW \& Chrousos GP 1995 Aging is associated in the 344/N Fischer rat with decreased stress responsivity of central and peripheral catecholaminergic systems and impairment of the hypothalamic-pituitaryadrenal axis. Annals of the New York Academy of Sciences 771 491-511. (doi:10.1111/j.1749-6632.1995.tb44705.x)

Correa da Costa VM \& Rosenthal D 1996 Effect of aging on thyroidal and pituitary $\mathrm{T}_{4}-5^{\prime}$-deiodinase activity in female rats. Life Sciences $\mathbf{5 9}$ 1515-1520. (doi:10.1016/0024-3205(96)00482-1)

Denef C 2008 Paracrinicity: the story of 30 years of cellular pituitary crosstalk. Journal of Neuroendocrinology 20 1-70. (doi:10.1111/j.1365-2826.2008. 01676.x)

Donda A, Reymond F, Rey F \& Lemarchand-Béraud T 1990 Sex steroids modulate the pituitary parameters involved in the regulation of TSH secretion in the rat. Acta Endocrinologica 122 577-584.

Filipović B, Sosić-Jurjević B, Ajdzanović V, Trifunović S, Manojlović-Stojanoski M, Ristić N, Nestorović N, Milosević V \& Sekulić M 2007 The effect of orchidectomy on thyroid C cells and bone histomorphometry in middle-aged rats. Histochemistry and Cell Biology 128 153-159. (doi:10.1007/s00418-007-0307-5)

Gentry RT \& Wade GN 1976 Androgenic control of food intake and body weight in male rats. Journal of Comparative and Physiological Psychology 90 18-25. (doi:10.1037/h0077264)

Harman SM, Metter EJ, Tobin JD, Pearson J \& Blackman MR 2001 Longitudinal effects of aging on serum total and free testosterone levels in healthy men, Baltimore Longitudinal Study of Aging. Journal of Clinical Endocrinology and Metabolism 86 724-731. (doi:10.1210/jc.86.2.724)

Harris AR, Fang SL, Hinerfeld L, Braverman LE \& Vagenakis AG 1979 The role of sulfhydryl groups on the impaired hepatic $3^{\prime}, 3,5$-triiodothyronine generation from thyroxine in the hypothyroid, starved, fetal, and neonatal rodent. Journal of Clinical Investigation 63 516-524. (doi:10.1172/ JCI109330)

Köhrle J 1994 Thyroid hormone deiodination in target tissues - a regulatory role for the trace element selenium? Experimental and Clinical Endocrinology 102 63-89. (doi:10.1055/s-0029-1211267)

Köhrle J 2002 Iodothyronine deiodinases. Methods in Enzymology 347 125-167. (doi:10.1016/S0076-6879(02)47014-0)

Köhrle J, Schomburg L, Drescher S, Fekete E \& Bauer K 1995 Rapid stimulation of type I $5^{\prime}$-deiodinase in rat pituitaries by $3,3^{\prime}, 5$-triiodoL-thyronine. Molecular and Cellular Endocrinology 108 17-21. (doi:10.1016/ 0303-7207(95)92574-8)

Lamberts SW, van den Beld AW \& van der Lely AJ 1997 The endocrinology of aging. Science 278 419-424. (doi:10.1126/science.278.5337.419)

Liao XH, Di Cosmo C, Dumitrescu AM, Hernandez A, Van Sande J, St Germain DL, Weiss RE, Galton VA \& Refetoff S 2011 Distinct roles of deiodinases on the phenotype of Mct8 defect: a comparison of eight different mouse genotypes. Endocrinology 152 1180-1191. (doi:10.1210/ en.2010-0900)

Lisbôa PC, Curty FH, Moreira RM, Oliveira KJ \& Pazos-Moura CC 2001 Sex steroids modulate rat anterior pituitary and liver iodothyronine deiodinase activities. Hormone and Metabolic Research 33 532-535. (doi:10.1055/s-2001-17211)

Marassi MP, Fortunato RS, da Silva AC, Pereira VS, Carvalho DP, Rosenthal D \& da Costa VM 2007 Sexual dimorphism in thyroid function and type 1 iodothyronine deiodinase activity in pre-pubertal and adult rats. Journal of Endocrinology 192 121-130. (doi:10.1677/joe.1.06901)

Mariotti S, Franceschi C, Cossarizza A \& Pinchera A 1995 The aging thyroid. Endocrine Reviews 16 686-715. (doi:10.1210/edrv-16-6-686)

Matsumoto AM 2002 Andropause: clinical implications of the decline in serum testosterone levels with aging in men. Journals of Gerontology. Series A, Biological Sciences and Medical Sciences 57 M76-M99. (doi:10.1093/gerona/ 57.2.M76)

Miyashita K, Murakami M, Iriuchijima T, Takeuchi T \& Mori M 1995 Regulation of rat liver type 1 iodothyronine deiodinase mRNA levels by testosterone. Molecular and Cellular Endocrinology 115 161-167. (doi:10.1016/0303-7207(95)03689-X)

Mooradian AD, Deebaj L \& Wong NC 1991 Age-related alterations in the response of hepatic lipogenic enzymes to altered thyroid states in the rat. Journal of Endocrinology 128 79-84. (doi:10.1677/joe.0.1280079)

Morganti S, Ceda GP, Saccani M, Milli B, Ugolotti D, Prampolini R, Maggio M, Valenti G \& Ceresini G 2005 Thyroid disease in the elderly: sex-related differences in clinical expression. Journal of Endocrinological Investigation 28 101-104.

Nève P \& Rondeaux P 1991 Age-related accumulation of lysosomes and other cytological features in active thyroid follicles of the CBA mouse. Cell and Tissue Research 265 275-285. (doi:10.1007/BF00398075)

Pelletier G \& El-Alfy M 2000 Immunocytochemical localization of estrogen receptors alpha and beta in the human reproductive organs. Journal of Clinical Endocrinology and Metabolism 85 4835-4840. (doi:10.1210/ jc.85.12.4835)

Pfaffl MW 2001 A new mathematical model for relative quantification in realtime RT-PCR. Nucleic Acids Research 29 e45. (doi:10.1093/nar/29.9.e45)

Rao-Rupanagudi S, Heywood R \& Gopinath C 1992 Age-related changes in thyroid structure and function in Sprague-Dawley rats. Veterinary Pathology 29 278-287. (doi:10.1177/030098589202900402)

Reymond F, Dénéréaz N \& Lemarchand-Béraud T 1992 Thyrotropin action is impaired in the thyroid gland of old rats. Acta Endocrinologica 126 55-63.

Rincon J, Holmäng A, Wahlström EO, Lönnroth P, Björntorp P, Zierath JR \& Wallberg-Henriksson H 1996 Mechanisms behind insulin resistance in rat skeletal muscle after oophorectomy and additional testosterone treatment. Diabetes 45 615-621. (doi:10.2337/diabetes.45.5.615)

Ron E, Kleinerman RA, Boice JD Jr, LiVolsi VA, Flannery JT \& Fraumeni JF Jr 1987 A population-based case-control study of thyroid cancer. Journal of the National Cancer Institute 79 1-12. (doi:10.1093/jnci/79.1.1)

Schomburg L \& Bauer K 1997 Regulation of the adenohypophyseal thyrotropin-releasing hormone-degrading ectoenzyme by estradiol. Endocrinology 138 3587-3593. (doi:10.1210/en.138.9.3587) 
Schomburg L, Riese C, Michaelis M, Griebert E, Klein MO, Sapin R, Schweizer U \& Köhrle J 2006 Synthesis and metabolism of thyroid hormones is preferentially maintained in selenium-deficient transgenic mice. Endocrinology 147 1306-1313. (doi:10.1210/ en.2005-1089)

Schomburg L, Riese C, Renko K \& Schweizer U 2007 Effect of age on sexually dimorphic selenoprotein expression in mice. Biological Chemistry 388 1035-1041. (doi:10.1515/BC.2007.128)

Schweizer U, Weitzel JM \& Schomburg L 2008 Think globally: act locally. New insights into the local regulation of thyroid hormone availability challenge long accepted dogmas. Molecular and Cellular Endocrinology 289 1-9. (doi:10.1016/j.mce.2008.04.007)

Sosić-Jurjević B, Filipović B, Ajdzanović V, Savin S, Nestorović N, Milosević V \& Sekulić M 2010 Suppressive effects of genistein and daidzein on pituitary-thyroid axis in orchidectomized middle-aged rats. Experimental Biology and Medicine 235 590-598. (doi:10.1258/ebm.2009.009279)

Stringer BM \& Wynford-Thomas D 1982 Importance of maintaining species homology in thyroid hormone radioimmunoassays: modification of 'human' radioimmunoassay kits for use with rat samples. Hormone Research 16 392-397. (doi:10.1159/000179530)
Surks MI \& Hollowell JG 2007 Age-specific distribution of serum thyrotropin and antithyroid antibodies in the US population: implications for the prevalence of subclinical hypothyroidism. Journal of Clinical Endocrinology and Metabolism 92 4575-4582. (doi:10.1210/jc.2007-1499)

Tamura S \& Fujita H 1981 Fine structural aspects on the cold follicles in the aged mouse thyroid. Archivum Histologicum Japonicum 44 177-188. (doi:10.1679/aohc1950.44.177)

Visser TJ 1996 Pathways of thyroid hormone metabolism. Acta Medica Austriaca 23 10-16.

Weibel ER 1979 Stereological Methods. Vol. I : Practical Methods for Biological Morphometry. pp 1-415 Academic Press, London.

Received in final form 3 September 2012

Accepted 6 September 2012

Made available online as an Accepted Preprint 6 September 2012 